\title{
Morphological errors in skills writing the requirement of the class vocational school of students Ceger private vocational schooleast Jakarta
}

\author{
Ila Nafilah *), \\ Universitas Indraprasta PGRI \\ Reni Rokhayati, \\ Universitas Indraprasta PGRI \\ Yulia Agustin, \\ Universitas Indraprasta PGRI \\ *) Correspondences author: J1. Raya Tengah No. 80, Kel. Gedong, Kec. Pasar Rebo, Jakarta Timur 13760, Indonesia; \\ e-mail: nafilah.salsabila@gmail.com
}

\begin{abstract}
Writing skills are one of four language skills, three of which are reading, listening and speaking. Writing is a means of expressing ideas or ideas to communicate indirectly to others so that the person understands them. There are four types of essays, which are essays of description, argumentation, persuasion and narrative. This study uses a qualitative descriptive approach that emphasizes the depth of appreciation of the interaction between concepts that are being studied empirically using words or images. Research with this qualitative approach uses content analysis method. The research method used to analyze the narrative essays is by using a qualitative method that focuses solely on morphological errors by examining the fields of affixation, reduplication, composition, and morphophonemic errors related to narrative essays of fifth grade students of elementary school (SD). The purpose of this research is to analyze and obtain a clear picture of morphological errors in narrative essay writing skills of fifth grade elementary school students.
\end{abstract}

Key Words: morphological errors, writing skills, narrative essays.

Article History: Received: 27/10/2018; Revised: 25/11/2018; Accepted: 18/12/2018; Published: 25/12/2018

How to Cite (MLA 7th): Nafilah, Ila, Reni Rokhayati, and Yulia Agustin. "Morphological errors in skills writing the requirement of the class vocational school of students Ceger private vocational schooleast Jakarta." Hortatori Jurnal Pendidikan Bahasa dan Sastra Indonesia 2.2 (2018): 100-108. Print/Online. Copyrights Holder: Nafilah, Ila, Reni Rokhayati, and Yulia Agustin. First Publication: Hortatori Jurnal Pendidikan Bahasa dan Sastra Indonesia (2018).

This work is licensed under a Creative Commons Attribution-ShareAlike 4.0 International License.

\section{Pendahuluan}

Analisis kesalahan berbahasa sangat bermanfaat dalam kegiatan sehari-hari, sebab melalui analisis kesalahan berbahasa, seseorang dapat menjelaskan penggunaan bahasa Indonesia yang baik dan benar sehingga komunikasi dapat berjalan dengan efekitf. Selain itu, Analisis kesalahan berbahasa bertujuan untuk mendeskripsikan kesalahan pelajar dalam mempelajari bahasa kedua. Hasil dari analisis kesalahan berbahasa ini kemudian dijadikan acuan pokok bagi para guru untuk lebih menekankan aspek kebahasaan tertentu yang merupakan wilayah terjadinya kesalahan pada siswa sebagai pembelajar.

Terdapat dua faktor yang menjadi kesalahan bagi siswa dalam pembelajaran bahasa. Faktor tersebut terdiri dari faktor internal dan eksternal. Faktor internal terjadi bila kesalahan berbahasa tersebut disebabkan oleh siswa/pelajar itu sendiri (kesalahan dari dalam siswa), sedangkan faktor eksternal terjadi bila kesalahan berbahasa itu berasal dari luar lingkungan siswa, salah satu di antaranya adalah kesalahan siswa yang disebabkan oleh kesalahan guru dalam mentransfer pengetahuan kepada siswa, khususnya tentang pengetahuan pembelajaran bahasa kedua di lingkungan sekolah. 
Tataran dalam ilmu linguistik (bahasa) terdiri dari fonologi, morfologi, sintaksis, dan wacana. Salah satu bentuk kesalahan berbahasa yang sering dilakukan guru pada saat mengajar adalah kesalahan pada tataran morfologi. Kesalahan pada bidang morfologi ini dapat berupa kesalahan bentuk kata, kesalahan penggunaan afiksasi, kesalahan penggunaan reduplikasi dan kesalahan penggunaan komposisi suatu bahasa. Kesalahan berbahasa terjadi karena adanya penyimpangan terhadap kaidah-kaidah kebahasaan yang dilakukan oleh pembelajar ketika siswa menggunakan bahasa. Penyimpangan yang dimaksud dalam hal ini adalah penyimpangan yang bersifat sistematis, yakni penyimpangan yang berhubungan dengan kompetensi.

Penelitian ini berkenaan dengan kesalahan berbahasa tulis, yaitu kesalahan mengarang dalam bahasa Indonesia sebagai bahasa kedua. Berdasarkan hasil karangan para siswa yang diperoleh langsung dari pengajar mata pelajaran bahasa Indonesia khususnya mengarang bahwa masih banyak ditemukan kesalahan-kesalahan dalam tulisan para siswa. Jika dilihat dari segi analisis kesalahan berdasarkan linguistik, penyebab kesalahan tersebut adalah (1) akibat pengaruh bahasa sumber (bahasa ibu/bahasa pertama) terhadap bahasa target (bahasa kedua) yang biasa disebut kesalahan interlingual (interlanguage errors), dan (2) akibat pengaruh antar unsur-unsur di dalam bahasa target (bahasa kedua) itu sendiri yang biasa disebut kesalahan intralingual (intralanguage).

1. Hakikat Analisis Kesalahan

Setyawati (2010:13) menyatakan bahwa dalam bahasa Indonesia terdapat beberapa kata yang artinya bernuansa dengan kesalahan yaitu; penyimpangan, pelanggaran, dan kekhilafan. Setyawati (2010:13-14) mengemukakan bahwa keempat kata itu dapat dideskripsikan artinya sebagai berikut:

a) Kata 'salah' diantonimkan dengan 'betul', artinya apa yang dilakukan tidak betul, tidak menurut norma, tidak menurut aturan yang ditentukan. Hal tersebut mungkin disebabkan oleh pemakai bahasa yang belum tahu, atau tidak tahu terdapat norma, kemungkinan yang lain dia khilaf. Jika kesalahan ini dikaitkan dengan penggunaan kata, dia tidak tahu kata yang tepat dipakai.

b) 'Penyimpangan' dapat diartikan menyimpang dari norma yang telah ditetapkan. Pemakai bahasa menyimpang karena tidak mau, enggan, malas mengikuti norma yang ada. Sebenarnya pemakai norma bahasa tersebut tahu norma yang benar, tetapi dia memakai norma lain yang dianggap lebih sesuai dengan konsepnya. Kemungkinan lain penyimpangan disebabkan oleh keinginan yang kuat yang tidak dapat dihindari karena satu dan lain hal. Sikap berbahasa ini cenderung menuju ke pembentukan kata, istilah, slang, jargon, bisa juga prokem.

c) 'Pelanggaran' terkesan negatif karena pemakai bahasa dengan penuh kesadaran tidak mau menurut norma yang telah ditentukan, sekalipun dia mengetahui bahwa yang dilakukan berakibat tidak baik. Sikap tidak disiplin terhadap media yang digunakan seringkali tidak mampu menyampaikan pesan dengan tepat.

d) 'Kekhilafan' merupakan proses psikologis yang dalam hal ini menandai seseorang khilaf menerapkan teori atau norma bahasa yang ada pada dirinya, khilaf menyebabkan sikap keliru memakai. Kekhilafan dapat diartikan kekeliruan. Kemungkinan salah ucap, salah susun karena kurang cermat.

2. Hakikat Morfologi

Secara etimologi kata morfologi berasal dari kata morf yang berarti 'bentuk' dan kata logi yang berarti 'ilmu mengenai bentuk'. Di dalam kajian linguistik, morfologi berarti 'ilmu mengenai bentuk-bentuk dan pembentukan kata' (Chaer, 2015:3). Dalam mempelajari bahasa sebagai alat komunnikasi akan terkait erat dengan yang namanya morfologi, yaitu bidang linguistik yang mempelajari bagian dari struktur bahasa yang mencakup kata dan bagian-bagian kata, yaitu morfem. Morfologi menjadi penting dalam pembelajaran bahasa karena memiliki peran penting pembentukan morfem sebagai dasar pembentukan frase, klausa, kalimat, paragraf, serta wacana (Rohmadi, 2009: 3). 
Arifin, (2014:2) Morfologi adalah studi linguistik yang menyelidiki seluk beluk bentuk kata. Dengan demikian morfologi adalah ilmu yang mempelajari seluk beluk pembentukan kata. Chaer (2008: 3) juga berpendapat secara etimologi kata morfologi berasal dari kata morf yang berarti 'bentuk' dan kata logi yang berarti 'ilmu'. Jadi secara harfiah kata morfologi berarti ilmu mengenai bentuk. Jadi, berdasarkan pendapat para ahli di atas dapat disimpulkan bahwa morfologi adalah bidang ilmu linguistik yang mempelajari pembentukan kata.

3. Hakikat Keterampilan Menulis

Saddhono (2012: 96) mengemukakan bahwa keterampilan menulis merupakan salah satu dari keterampilan berbahasa yang dikuasai seseorang sesudah menguasai keterampilan menyimak, berbicara, dan membaca. Nurudin (2010: 4) berpendapat bahwa menulis adalah segenap rangkaian kegiatan seseorang dalam rangka mengungkapkan gagasan dan menyampaikannya melalui bahasa tulis kepada orang lain agar mudah dipahami. Tarigan (2008: 3) mengatakan bahwa menulis merupakan suatu keterampilan berbahasa yang dipergunakan untuk berkomunikasi secara tidak langsung, tidak secara tatap muka dengan orang lain.

\section{Hakikat Karangan Narasi}

Alek (2011 : 184) menyatakan bahwa penulisan yang sifatnya bercerita, baik berdasarkan pengamatan maupun perekaan, dan tujuannya lebih banyak menghimpun, tergolong kategori pengisahan. Hasilnya dapat disebut kisahan atau narasi. Karangan narasi biasanya dihubunghubungkan dengan cerita. Oleh sebab itu, sebuah karangan narasi atau paragraf naratif banyak kita temukan dalam novel, cerpen atau hikayat (Arifin, $2012: 174$ ).

\section{Metode}

Penelitian ini menggunakan pendekatan deskriptif kualitatif yang mengedepankan kedalaman penghayatan terhadap interaksi antarkonsep yang sedang dikaji secara empiris dengan menggunakan katakata atau gambar. Penelitian dengan pendekatan kualitatif ini menggunakan metode analisis isi (content analysis). Analisis isi ini digunakan dalam pencarian fakta dengan interpretasi data berupa karangan narasi siswa kelas V Sekolah Dasar (SD). Analisis yang dilakukan adalah analisis terhadap kesalahan morfologi.

Teknik penelitian deskriptif yang dilakukan peneliti adalah teknik meneliti kesalahan berbahasa. Teknik penelitian ini dapat dilakukan dengan membaca secara teliti karangan narasi siswa kelas V Sekolah Dasar (SD) yang terdapat dalam sumber data, mengidentifikasi, mengklasifikasi, menganalisis, dan menyimpulkan data-data hasil penelitian mengenai kesalahan morfologi dalam karangan narasi siswa kelas V Sekolah Dasar (SD). Jadi, analisis isi adalah penelitian yang berusaha menganalisis dokumen untuk mengetahui isi dan makna yang terkandung dalam dokumen tersebut. Sehubungan dengan tujuan khusus penelitian, maka penelitian ini memfokuskan pada kesalahan morfologi dalam karangan narasi siswa kelas V Sekolah Dasar Negeri (SDN). Subfokus dalam penelitian ini yaitu bidang morfologi yang terdiri dari empat aspek yaitu: afiksasi, reduplikasi, komposisi dan morfofonemik.

\section{Hasil dan Diskusi}

Deskripsi informasi penelitian adalah gambaran mengenai data yang diteliti. Data kesalahan morfologi yang diteliti bersumber dari karangan narasi siswa kelas V Sekolah Dasar Negeri (SDN) Ceger Jakarta Timur. Kesalahan morfologi yang terdapat dalam karangan narasi siswa kelas V Sekolah Dasar Negeri Ceger Jakarta Timur akan diteliti berdasarkan kesalahan bidang morfologi di antaranya: afiksasi, reduplikasi, komposisi, dan morfofonemik.

Data karangan narasi siswa kelas V Sekolah Dasar Negeri (SDN) Ceger Jakarta timur yang akan diteliti berjumlah 18 siswa. Hasil penelitian akan dijelaskan berdasarkan klasifikasi kesalahan afiksasi, reduplikasi, komposisi, dan morfofonemik. Deskripsi hasil penelitian akan dilengkapi pula dengan rekapitulasi kesalahan morfologi seperti afiksasi, reduplikasi, komposisi, dan morfofonemik. 
Analisis kesalahan morfologi dilakukan dengan cara mencatat di dalam kartu data penelitian mengenai beberapa karangan narasi siswa kelas V Sekolah Dasar Negeri yang terdapat kesalahan dalam bidang morfologi, seperti afiksasi, reduplikasi, komposisi, dan morfofonemik. Setelah melakukan pencatatan, kemudian peneliti mengklasifikasikan berdasarkan tipe-tipe kesalahan morfologi yang terdapat dalam karangan narasi siswa kelas V Sekolah Dasar Negeri tersebut.

\section{Analisis Data}

\section{Kesalahan Afiksasi}

Data kesalahan afiksasi yang ditemukan dalam karangan narasi siswa kelas V Sekolah Dasar Negeri Ceger Jakarta Timur berjumlah sepuluh kesalahan, di antaranya sebagai berikut:

a. Nama siswa

Judul karangan

Kalimat

Kesalahan berbahasa

b. Nama siswa

Judul karangan

Kalimat

Kesalahan berbahasa

c. Nama siswa

Judul karangan

Kalimat

Kesalahan berbahasa

d. Nama siswa

Judul karangan

Kalimat

Kesalahan berbahasa

e. Nama siswa

Judul karangan

Kalimat

Kesalahan berbahasa

f. Nama siswa

Judul karangan

Kalimat

Kesalahan berbahasa

g. Nama siswa
: Nayla

: Berlibur ke Monumen Pancasila

: Sesampai di tempat duduk, saya pun makan dan minum.

: Sesampai (seharusnya sesampainya)

: Regina

: Berlibur ke Kebun Binatang

: Sesampai di area menunggang gajah mereka antri untuk dapat merasakan sensasi menunggang gajah.

: Sesampai (seharusnya sesampainya)

: Novita Dwi Putriani

: Berlibur di Pulau Bali

: Dan keesokannya harinya aku dan keluargaku

berangkat dari kota Bandar Lampung pukul. 06.00

WIB menuju bandara Raden Intan.

: keesokannya (seharusnya keesokan)

: Sadrina Nur Qud Siyya

: Berlibur ke Rumah Kakek

: Hasilnya bisa makan di kebun atau dibawa pulang.

: makan (seharusnya dimakan)

: Ide Nur Diana

: Berlibur ke Cipanas

: Pukul. 07.30 kami kumpul di depan pintu gerbang

Taman Mini Indonesia Indah.

: kumpul (seharusnya berkumpul)

: Nova Aprilia

: Liburan ke Desa Kakek di Bandung

: Aku pun bangun pagi dengan senang aku langsung siap-siap.

: siap-siap (seharusnya bersiap-siap)

: Nova Aprilia 
Judul karangan

Kalimat

Kesalahan berbahasa

h. Nama siswa

Judul karangan

Kalimat

Kesalahan berbahasa

i. Nama siswa

Judul karangan

Kalimat

Kesalahan berbahasa

j. Nama siswa

Judul karangan

Kalimat

Kesalahan berbahasa

k. Nama siswa

Judul karangan

Kalimat

Kesalahan berbahasa
: Liburan ke Desa Kakek di Bandung

: Sesampai di rumah kakek ibuku membangunin aku yang sedang tertidur pulas.

: Sesampai (seharusnya Sesampainya)

: Bagus Satria Ramadhan

: Berkunjung ke Kebun Binatang

: .... Jalan yang kami tempuh sangat jauh dan melalui jembatan terpanjang se asia tenggara yaitu jembatan Suramadu.

: se asia tenggara (seharusnya se-Asia Tenggara)

\section{: Alfrida}

: Liburan ke Rumah Nenek

: Di sana, aku melihat banyak orang yang ingin pergi untuk berliburan.

: berliburan (seharusnya liburan/berlibur)

: Marsyah Dwi Anita

: Berlibur ke Pantai Cirata

: Aku menyiapkan makanan dan minuman untuk kami nikmat di sana.

: nikmat (seharusnya nikmati)

: Radit

: Liburan ke Pantai

: Sesampai di rumah aku dan adikku langsung ke rumah temanku aku mengasih tau temanku selagi waktu itu aku di pantai Indrayanti, dan Siung.

: sesampai (seharusnya sesampainya)

\section{Kesalahan Reduplikasi}

a. Nama siswa

Judul karangan

Kalimat

Kesalahan berbahasa

b. Nama siswa

Judul karangan

Kalimat

Kesalahan berbahasa

c. Nama siswa

Judul karangan

Kalimat

\section{: Salwa Naysillah R}

: Berlibur Bersama Keluarga

: Saya pergi ke 3 Rekomendasi destinasi wisata yang ramai anak2 di puncak.

: anak2 (seharusnya anak-anak)

: Amira Rodiatul A

: Berlibur ke Ciater

: Aku dan adikku terkagum dengan keindahan alam itu.

: terkagum (seharusnya terkagum-kagum)

: Nissa Azahriel

: Berkunjung ke Rumah Nenek di Sukabumi

: ku pandangi wajah nenek, terlihat guratan-gurutan

yang menenjukkan sisa-sisa kecantikkan di masa 
Kesalahan berbahasa

d. Nama siswa

Judul karangan

Kalimat

Kesalahan berbahasa

e. Nama siswa

Judul karangan

Kalimat

Kesalahan berbahasa

f. Nama siswa

Judul karangan

Kalimat

Kesalahan berbahasa

g. Nama siswa

Judul karangan

Kalimat

Kesalahan berbahasa

h. Nama siswa

Judul karangan

Kalimat

Kesalahan berbahasa

\section{Kesalahan Komposisi}

a. Nama siswa

Judul karangan

Kalimat

Kesalahan berbahasa

b. Nama siswa

Judul karangan

Kalimat

Kesalahan berbahasa mudahnya.

: guratan-gurutan (seharusnya guratan-guratan)

: Radit

: Liburan ke Pantai

: Kami semua bermain air bersama.

: bersama (seharusnya bersama-sama)

: Bagus Satria Ramadhan

: Berkunjung ke Kebun Binatang

:.... Kita hanya boleh melihat hewan hewan yang berkeliaran itu dari luar kandangnya ....

: hewan hewan (seharusnya hewan-hewan)

: M. Faiz Akrom

: Liburan ke Rumah Nenek

: Ikut bergabung bermain bersama teman di desa itu.

: teman (seharusnya teman-teman)

\section{: Rizky B}

: Liburan Sekolah

: Aku dan seluruh keluargaku tidak meyiakan waktu ini untuk mengadakan liburan keluarga.

: meyiakan (seharusnya menyia-nyiakan)

: Rizky B

: Liburan Sekolah

: Dengan canda canda dan tawa.

: canda canda (seharusnya canda-canda)

: Nova Aprilia

: Liburan ke Desa Kakek di Bandung

: Berapa jam kemudian aku pun dengan senang hati menaiki kereta api.

: Berapa jam (seharusnya Beberapa jam)

: Radit

: Liburan ke Pantai

: Sesampai di rumah aku dan adikku langsung ke rumah temanku aku mengasih tau temanku selagi waktu itu aku di pantai Indrayanti, dan Siung.

: mengasih tau (seharusnya memberi tahu) selagi waktu itu (seharusnya selagi waktu / selama aku). 
c. Nama siswa

Judul karangan

Kalimat

Kesalahan berbahasa

d. Nama siswa

Judul karangan

Kalimat

Kesalahan berbahasa

e. Nama siswa

Judul karangan

Kalimat

Kesalahan berbahasa

f. Nama siswa

Judul karangan

Kalimat

Kesalahan berbahasa

\section{: Alfrida}

: Liburan ke Rumah Nenek

: dan akhirnya aku, keluargaku, dan semua orang yang berada di bus beristirahat di fess area untuk membeli makanan dan minuman ringan.

: fess area (seharusnya rest area)

: Sopwatun Nabila L.

: Berlibur ke Pantai Carita

: Pada hari kamis, tepatnya pukul 08.30 pagi, aku dan keluarga ku berlibur ke Pantai Carita.

: pukul 08.30 pagi (seharusnya pukul 08.30)

: Nissa Azahriel

: Berkunjung ke Rumah Nenek di Sukabumi

: ku pandangi wajah nenek, terlihat guratan-gurutan yang menenjukkan sisa-sisa kecantikkan di masa mudahnya.

: di masa mudahnya (seharusnya di masa mudanya)

: Nazla Sausan Alody

: Liburan ke Rumah Nenek

: Ada yang menyabit padi, ada pula yang menyerontokkan butir padi dengan alat perontik padi.

: perontik padi (seharusnya perontok padi)

\section{Kesalahan Morfofonemik}

a. Nama siswa

Judul karangan

Kalimat

Kesalahan berbahasa

b. Nama siswa

Judul karangan

Kalimat

Kesalahan berbahasa

c. Nama siswa

Judul karangan

Kalimat

Kesalahan berbahasa
: Nissa Azahriel

: Berkunjung ke Rumah Nenek di Sukabumi

: ku pandangi wajah nenek, terlihat guratan-gurutan yang menenjukkan sisa-sisa kecantikkan di masa mudahnya.

: kecantikkan (seharusnya kecantikan)

: Nova Aprilia

: Liburan ke Desa Kakek di Bandung

: Sesampai di rumah kakek ibuku membangunin aku yang sedang tertidur pulas.

: membangunin (seharusnya membangunkan)

: Rizky B

: Liburan Sekolah

: Aku dan seluruh keluargaku tidak meyiakan waktu ini untuk mengadakan liburan keluarga.

: meyiakan (seharusnya menyiakan) 
d. Nama siswa

Judul karangan

Kalimat

Kesalahan berbahasa

e. Nama siswa

Judul karangan

Kalimat

Kesalahan berbahasa

f. Nama siswa

Judul karangan

Kalimat

Kesalahan berbahasa
: Rizky B

: Liburan Sekolah

: Pagi-pagi aku telah berbenah dan meyiapkan semua perbekalan yang nantinya diperlukan.

: meyiapkan (seharusnya menyiapkan)

: Rizky B

: Liburan Sekolah

: Tanpa meyia-yiakan waktu, aku mengajak kakek ku untuk bermain air.

: meyia-yiakan (seharusnya menyia-nyiakan)

: Nazla Sausan Alody

: Liburan ke Rumah Nenek

: Ada yang menyabit padi, ada pula yang menyerontokkan butir padi dengan alat perontik padi. : menyerontokkan (seharusnya merontokkan)

\section{Simpulan}

Setelah melakukan penelitian yang mendalam dengan menganalisis dan mengklasifikasikan kesalahan morfologi yang terdapat dalam karangan narasi siswa kelas V Sekolah Dasar Negeri Ceger Jakarta Timur maka dapat disimpulkan sebagai berikut: 1) Karangan narasi siswa kelas V Sekolah Dasar Negeri Ceger Jakarta Timur ditemukan data sebanyak 31 buah kesalahan morfologi di antaranya afiksasi, reduplikasi, komposisi, dan morfofonemik; 2) Karangan narasi siswa kelas V Sekolah Dasar Negeri Ceger Jakarta Timur terdapat kesalahan bidang morfologi di antaranya: afiksasi berjumlah 11 buah temuan atau $35 \%$, reduplikasi berjumlah 8 buah temuan atau $27 \%$, komposisi berjumlah 6 buah temuan atau $19 \%$, dan morfofonemik berjumlah 6 buah temuan atau $19 \%$; 3) Kajian kesalahan morfologi dalam karangan narasi siswa kelas V Sekolah Dasar Negeri Ceger Jakarta Timur masih banyak ditemukan kesalahan afiksasi yaitu sebanyak 11 buah temuan atau $35 \%$.

\section{Ucapan Terima Kasih}

Terima kasih kepada semua pihak yang membantu penulis dalam menyelesaikan artikel hasil riset ini sehingga bisa diterbitkan di Jurnal Hortatori.

\section{Daftar Rujukan}

Alek dan Achmad H.P. 2011. Bahasa Indonesia Untuk Perguruan Tinggi. Jakarta: Kencana.

Arifin, E. Zaenal dan S. Amran Tasai. 2012. Bahasa Indonesia: Sebagai Mata Kuliah Pengembangan dan Kepribadian. Tangerang : Pustaka Mandiri.

Arifin, E. Zaenal. 2014. Morfologi Bahasa Indonesia: Untuk Program Studi Pendidikan Bahasa dan Sastra. Tangerang: Pustaka Mandiri.

Arifin, E. Zaenal. 2015. Asas-Asas Linguistik Umum. Tangerang: Pustaka Mandiri.

Chaer, Abdul. 2008. Morfologi Bahasa Indonesia. Jakarta: Rineka Cipta.

Chaer, Abdul. 2014. Linguistik Umum. Jakarta: Rineka Cipta.

Chaer, Abdul. 2015. Morfologi Bahasa Indonesia: Pendekatan Proses. Jakarta: Rineka Cipta.

Nurudin. 2010. Dasar-Dasar Penulisan. Malang: UMM press. 
108 Morphological errors in skills writing the requirement of the class vocational school of students Ceger private vocational schooleast Jakarta

Rohmadi, dkk. 2009. Morfologi, Telaah Morfem dan Kata. Surakarta: Yuma Pustaka.

Saddhono, Kundaru dan St. Y. Slamet. 2012. Meningkatkan Keterampilan Berbahasa Indoensia, Teori, dan Aplikasi. Bandung: Karya Putra Darwati.

Setyawati, Nanik. 2010. Analisis kesalahan berbahasa Indonesia: teori dan praktik. Cet. 2. Surakarta: Yuma Pustaka.

Slamet. 2008. Dasar-Dasar Keterampilan Berbahasa Indonesia. Lembaga Pengembangan Pendidikan UNS dan UPT Penerbit dan Percetakan UNS (unspress).

Tarigan, Henry Guntur. 2008. Menulis :Sebagai Suatu Ketrampilan Berbahasa. Bandung: Angkasa.

Tarigan, Henry Guntur. 2008. Menulis. Bandung : Angkasa.

Yulianto, Bambang dan Maria Mintowati. 2009. Analisis Kesalahan Berbahasa. Jakarta: Universitas Terbuka. 